\title{
SEASONAL AND HANDLING EFFECTS ON MILK QUALITY FROM PIRES RURAL PRODUCERS ASSOCIATION
}

João Paulo Pacheco Rodrigues ${ }^{1 *}$; Marcos Inácio Marcondes ${ }^{1}$; Rogério de Paula Lana ${ }^{1}$; Thiago Carvalho da Silva ${ }^{1}$; Luana Marta de Almeida Rufino ${ }^{1}$

\begin{abstract}
This study was conducted to evaluate the effects of year seasons, refrigeration methods, transport and number of milking sessions on the quality of milk produced by farmers members of an association in Juiz de Fora, Minas Gerais, Brazil. In the years 2009 and 2010, monthly milk samples from each property were collected to analysis contents of fat (FAT), protein (PRO), nonfat solids (NFS), somatic cell count (SCC) and total bacterial count (TBC). The effects of months, year season, types of refrigeration at the property, transportation methods and number of milking sessions were evaluated. The results were analyzed in mixed model, assessing the effects of year season on all characteristics (FAT, PRO, NFS, SCC and TBC) and effects of transport, refrigeration and number of milking sessions on SCC and TBC. There was effect of season in all evaluated characteristics, with greater contents of FAT, PRO and NFS in autumn. Total bacterial count was lower in winter and higher in spring, while the SCC was lower in summer and higher in autumn. There was no effect of transportation or refrigeration on SCC, but they affected TBC. Somatic cell count varied according to number of milking sessions. Year season, transport type, refrigeration method and number of milking sessions influence the milk quality.
\end{abstract}

Keywords: associativism, centesimal composition, family farming, somatic cell count, total bacterial count.

\section{EFEITOS SAZONAIS E DE MANEJO SOBRE A QUALIDADE DO LEITE DA ASSOCIAÇÃO DE PRODUTORES RURAIS DE PIRES}

\begin{abstract}
RESUMO-O estudo foi conduzido com o objetivo de avaliar os efeitos de época do ano, método de refrigeração, tipo de transporte e numero de ordenhas sobre a qualidade do leite produzido por membros de uma associação de produtores em Juiz de Fora, Minas Gerais. Foram coletadas, nos anos de 2009 e 2010, amostras mensais do leite de cada propriedade, para que fossem analisados os teores de gordura (GOR), proteína (PRO), extrato seco desengordurado (ESD), contagem de células somáticas (CCS) e bacteriana total (CBT). Avaliouse o efeito dos meses e estações do ano, tipos de refrigeração na propriedade, métodos de transporte e numero de ordenhas. Os resultados foram analisados em modelo misto, avaliando-se efeitos de épocas do ano sobre todas as características (GOR, PRO, ESD, CCS, CBT) e efeitos de transporte, refrigeração na propriedade e número de ordenhas sobre a CCS e CBT. Houve efeito da época do ano sobre todas as características, com maiores teores de GOR, PRO e ESD na estação de outono. A CBT foi menor no inverno e maior na primavera, e a CCS foi menor no verão e maior no outono. Não houve efeito do transporte e refrigeração sobre a CCS, mas esses influenciaram a CBT. A CCS variou de acordo com o número de ordenhas. A qualidade do leite é influenciada pela época do ano, tipo de transporte e de refrigeração e número de ordenhas.
\end{abstract}

Palavras chave: agricultura familiar, associativismo, composição centesimal, contagem bacteriana total, contagem de células somáticas.

\footnotetext{
${ }^{1}$ Department of Animal Science, Universidade Federal de Viçosa, Viçosa, 36570-900, Brazil;

* Corresponding author: joaopaulo0511@ hotmail.com
} 


\section{INTRODUCTION}

The milk production chain can be found in all the Brazilian regions (Lopes et al., 2007). This segment stands for one of the most important activities for the generation of employment and income in the rural areas; it is present in $36 \%$ of the family farming establishments in Brazil (Zoccal et al., 2004).

In the 90s, the Brazilian agro industrial milk system went through innumerable changes, in which the process of refrigeration and transport with bulk tank stood out, which fostered the efficiency of the dairy industry and the improvement of the milk quality. However, this change hampered the situation of the smaller scale farmers (Galan, 1998). The purchase of cooling tanks for the milk refrigeration in the property represents a high cost of investment, and consequently stimulated the emergence of the joint acquisition of these products through farmers associations, as an alternative to meet the requirements of the Normative Instruction no. 51 (Brito \& Diniz, 2004).

The farmers associations, or development of social groups, is the best way to reach small farmer economic sustainability in the dairy sector, strengthening their agents through greater politic and market representativeness (Melo \& Reis, 2007).

The small properties are responsible for a big part of milk produced in Brazil. However, the nutritional and microbiological milk quality from these farms generally is more liable to environmental effects. This may be a result of low use of technologies and dependence of pasture to feed their herd.

The milk quality has become increasingly important due to its possible valuation regarding its compositional aspects; it is determinant at the price paid to the farmer, therefore identify factors that affect milk quality, especially in cases which the production system is sensitive to environmental factors is ever more relevant.

Concerning the importance of associativism as an alternative utilized by small milk farmers in Brazil, this study aimed to evaluate the effect of seasons of the year, methods of refrigerating milk at the property, types of transport and number of milking sessions on the quality of the milk produced in an association of rural farmers in Juiz de Fora, Minas Gerais, Brazil.

\section{MATERIALAND METHODS}

The study was held in Associação de Produtores Rurais de Pires (Pires Rural Producers Association APRPires), which is constituted of 38 farmers, who commercialize milk together, with average daily production between 15 and 400 liters, located in the micro region of Juiz de Fora, in the Zona da Mata of Minas Gerais, southeastern Brazil, at an altitude of 636 meters, latitude of $21^{\circ} 57^{\prime \prime}$ south and longitude of $43^{\circ} 32^{\prime \prime}$ west. The climate of the region, according to the Köppen classification is Cwa (tropical highland), defined as cold and dry in winter and hot and rainy in summer.

The properties characterization was done with information concerning the productive characteristics of each property, obtained in December 2010, through visits paid to the establishments and interview with farmers, constituting a history of each property. For the classification as family farming, the proportion of family labor equal or superior to $50 \%$ in relation to the total labor was considered. The classification for the transport systems utilized daily was: cart load (milk in the churn transported by an animal-traction vehicle), truck (milk in the churn transported every morning by a truck belonging to the association), car (delivery of the milk by the farmer in motor vehicle) and direct (milk in private tank transferred to a truck with isothermal tank). The milk refrigeration systems utilized at the properties were classified as: absent (when the farmers only performed morning milking), refrigerator (refrigeration of the milk in churn in the fridge), immersion (churn in immersion tank) and tank (milk in private cooling tank). The farmers of one milking session always carried it out in the morning. At the characterization of the group of farmers, the descriptive statistics was utilized; relative frequencies of the productive characteristics of units were calculated based on the number of observations (Table 1).

The monthly milk production from APRPires was recorded to characterize the production seasonality (Figure 1).

During the years 2009 and 2010, according to the norms of the Ministry of Agriculture, Livestock and Supply (Ministério da Agricultura, Pecuária e Abastecimento - MAPA), two samples (50 mL) of milk from each property, in the individual churns, were collected monthly, after all the logistic process of the property, to the community tank or directly to private tanks in the two cases in which the milk did not go 
Table 1 - Relative frequencies of each characteristic of milk production systems in the Pires Rural Producers Association (APRPires) in Juiz de Fora, Minas Gerais, in 2010

\begin{tabular}{|c|c|c|c|c|}
\hline Characteristic & \multicolumn{4}{|c|}{ Frequency, $\%$} \\
\hline Labor & \multicolumn{2}{|c|}{$\begin{array}{c}\text { Family farming } \\
71.05\end{array}$} & \multicolumn{2}{|c|}{$\begin{array}{l}\text { Hired } \\
28.95\end{array}$} \\
\hline Number of milkings & \multicolumn{2}{|c|}{ One } & & \\
\hline Milking system & \multicolumn{2}{|c|}{$\begin{array}{c}\text { Manually } \\
97.37\end{array}$} & \multicolumn{2}{|c|}{$\begin{array}{c}\text { Mechanical } \\
2.63\end{array}$} \\
\hline Cooling in the property & $\begin{array}{c}\text { Refrigerator } \\
21.05\end{array}$ & $\begin{array}{c}\text { Immersion } \\
26.32\end{array}$ & $\begin{array}{l}\text { Tank } \\
5.26\end{array}$ & $\begin{array}{c}\text { Absent } \\
47.37\end{array}$ \\
\hline Transport & $\begin{array}{l}\text { Truck } \\
73.68\end{array}$ & $\begin{array}{c}\text { Car } \\
15.79\end{array}$ & $\begin{array}{l}\text { Direct } \\
5.26\end{array}$ & $\begin{array}{c}\text { Cart load } \\
5.26\end{array}$ \\
\hline
\end{tabular}

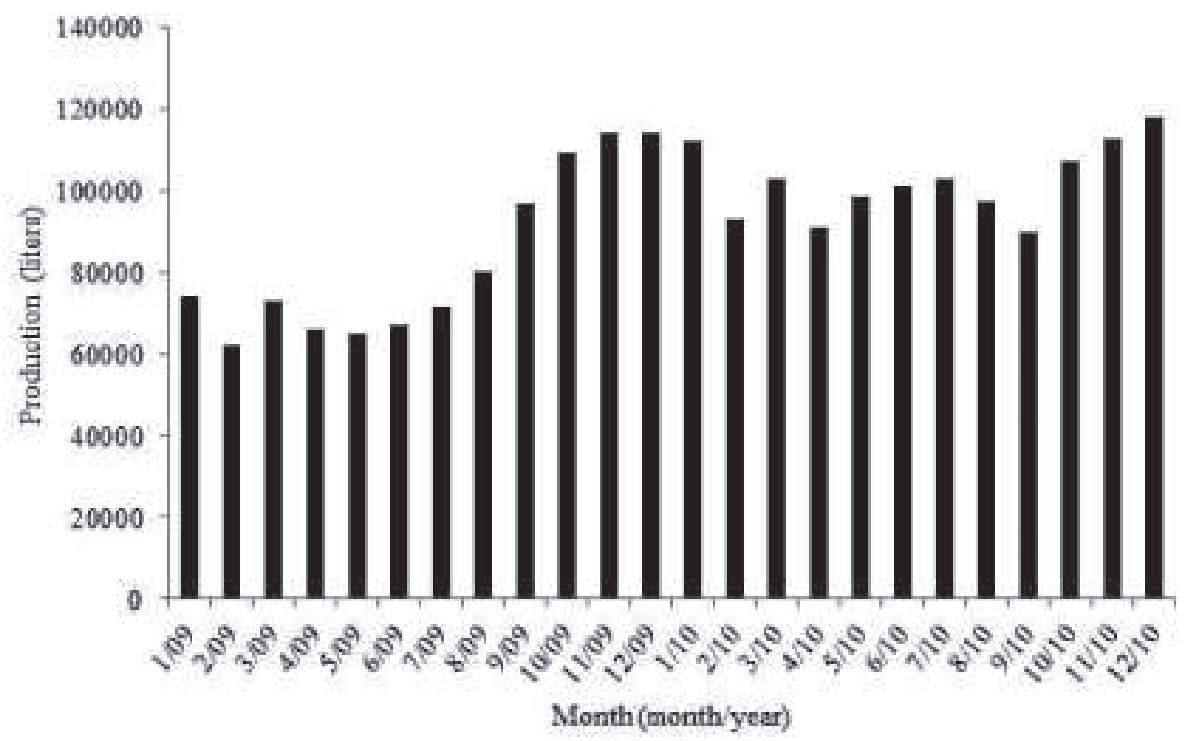

Figure 1 - Monthly milk production of the Pires Rural Producers Association (APRPires) in Juiz de Fora, Minas Gerais, in the years 2009 and 2010.

through this stage; the $72 \%$ Alizarol Alcohol test was previously conducted, and samples with positive results were discarded. The collected milk was sent to the Laboratory of Milk Quality (Laboratório de Qualidade do Leite - LQL) of Embrapa Gado de Leite, utilizing the preservative Bronopol@ (2-bromo-2-nitropropaneo1,3-diol and natamycin) for samples destined to somatic cells count (SCC), and Azidiol (chloramphenicol, sodium azide, sodium citrate and ethyl alcohol) for samples destined to total bacterial count (TBC), both analyzed by means of flow cytometry. The centesimal composition (fat, protein, lactose and nonfat solids (NFS)) was obtained from the same sample destined to SCC, by means of mid-infrared absorption.
For all the statistical analyses, the SCC values were transformed in somatic cell score (SCS) through the function SCS $=\left[\log _{2}(\mathrm{SCC} / 100,000)\right]+3($ Dabdoub $\&$ Shook, 1984). The values of TBC were transformed in base-10 logarithm (logTBC) (Santana et al., 2001).

At the evaluation of seasonality of milk components, SCC and TBC, the mixed model was employed, utilizing the split plot design with year as repeated measures, considering the year season and month nested in season as fixed effects, and property as random effect. The PROC MIXED from the software SAS (Statistical Analysis System, version 9.2) was utilized, with comparison of means through the Student's $t$ test by the PDIFF option. For the evaluation of effects of number of milking 
sessions, methods of refrigeration at the property of the milk collected in the afternoon and type of transport on SCC and TBC, the mixed model was employed, utilizing the split splot design with year as repeated measures, considering the type of transport, refrigeration and number of milking sessions as fixed effects and season (summer, autumn, winter and spring) month of the season and farmer as random effects. The PROC MIXED of the software SAS (Statistical Analysis System, version 9.2) was utilized; comparison of means was performed through the Student's $t$ test by the PDIFF option. Was adopted 0.10 as critical probability level for type I error for all comparisons.

\section{RESULTS AND DISCUSSION}

There were differences $(\mathrm{P}<0.10)$ between the monthly and season means in all characteristics of composition and quality of the milk produced by APRPires in 2009 and 2010 years (Table 2). Teixeira et al. (2003) also verified climate effect on milk composition and attributed these effects to consequences of environment on diets available to animals. The farmers from APRPires have seasonal production because of variations in the quality and availability of pasture (Figure 1). Likewise, not only production, but also the milk composition can be affected by variations occurring in the diets of farmers herds (Jenkins \& McGuire, 2006).

The seasonal effects on the milk quality (Table 2) are also important in the economic field, for they can determine variations in programs of payment for quality, which is a trend in the national market (Roma Júnior et al., 2009). Although there was no program of payment for quality in APRPires, throughout the study was observed a concern by the group to penalizing farmers who not follow the legislation standards, making the classification of all factors that affect the milk quality more important.

The year season with higher fat content was the autumn $(\mathrm{P}<0.10)$ (Table 2), a result also observed by Roma Junior et al. (2009). Is probable that a decline in pasture quality and amount during this season, caused a drop in production (Figure 1), which is associated with absence of roughage supplementation, this may explain the observed values from December to June (Table 2). After the autumn, the summer was the season that obtained more milk fat average $(\mathrm{P}<0.10)$. These observations can be explained by greater fiber availability in these periods, which increases the acetate:propionate ratio in rumen; the acetate is the main precursor of milk fat synthesis in mammary gland (Jenkins \& McGuire, 2006). The greater pasture supply in summer and autumn probably increased the fiber intake by the herds in these periods. It is coherent to observe that the highest value in autumn compared with the summer can also be a consequence of April results, the samples of this month in 2010 was classified as outliers, which are higher $(\mathrm{P}<0.10)$ than the general results behavior, probably due to problems in the samples collection or analysis.

The protein level was also higher in the autumn $(\mathrm{P}<0.10)$ (Table 2), a result which can be explained by the possible decrease in milk production and roughage:concentrate ratio in the diet of cows (Jenkins $\&$ McGuire, 2006). In this period, there is the beginning of the decline in forage supply, besides the good nutritional condition of the herds and presence, even if low, of concentrate supplementation for cows. Roma Junior et al. (2009) found the same result. After the autumn, spring had higher value $(\mathrm{P}<0.10)$. This season is the period when there is regrowth of pastures, which are characterized with higher protein and soluble carbohydrates. Such characteristics enable a greater production of microbial protein in the rumen, which, in larger amount, can increase the protein contents in the milk (Kalscheur et al., 2006), being a protein of good quality. According to Jenkins \& McGuire (2006), the availability of an amino acid profile close to that of the milk, in association with the availability of insulin into the lactating cow bloodstream can increase milk protein up to $0.5 \%$. The lowest value observed in the winter $(\mathrm{P}<0.10)$ must be due to low crude protein in animal diets.

The behavior of the NFS (Table 2) was similar to the protein, which was expected because protein represents a large part of that component, and the autumn was the season with highest values $(\mathrm{P}<0.10)$, but with little variation between months, probably because lactose is also representative for the characteristic. According to González (2001), lactose is a milk component of low variation considering the content, because of the close relationship between the amounts of lactose and water drained from the milk.

The results of TBC (Table 2), although being, in most of the observations, very high and of high variation 
Table 2 - Seasonal and monthly averages of fat, protein, nonfat solids, total bacterial count and somatic cell count, of the milk of properties in Pires Rural Producers Association (APRPires) in Juiz de Fora, Minas Gerais, in the years 2009 and 2010.

\begin{tabular}{|c|c|c|c|c|c|c|c|c|c|c|c|c|c|}
\hline \multicolumn{14}{|c|}{ Season } \\
\hline & & Summer & & & Autumn & & & Winter & & & Spring & & $\mathrm{CV}^{6}, \%$ \\
\hline Fat, g/kg & & $37.4^{\mathrm{b}}$ & & & $39.0^{\mathrm{a}}$ & & & $34.7^{\mathrm{c}}$ & & & $35.3^{\mathrm{c}}$ & & 14.88 \\
\hline $\mathrm{PRO}^{1}, \mathrm{~g} / \mathrm{kg}$ & & $32.5^{\mathrm{c}}$ & & & $34.3^{\mathrm{a}}$ & & & $31.8^{\mathrm{d}}$ & & & $33.2^{\mathrm{b}}$ & & 7.87 \\
\hline $\mathrm{NFS}^{1}, \mathrm{~g} / \mathrm{kg}$ & & $85.8^{\mathrm{c}}$ & & & $87.5^{\mathrm{a}}$ & & & $86.5^{\mathrm{b}}$ & & & $86.1^{\mathrm{bc}}$ & & 3.72 \\
\hline $\log \mathrm{TBC}^{4}$ & & $2.81^{\mathrm{a}}$ & & & $2.80^{\mathrm{ab}}$ & & & $2.73^{b}$ & & & $2.84^{\mathrm{a}}$ & & 18.20 \\
\hline \multirow[t]{3}{*}{$\mathrm{SCS}^{5}$} & & $4.65^{\mathrm{b}}$ & & & $5.07^{\mathrm{a}}$ & & & $4.83^{\mathrm{b}}$ & & & $4.76^{\mathrm{b}}$ & & 27.46 \\
\hline & \multicolumn{13}{|c|}{ Month } \\
\hline & Jan & Feb & Mar & Apr & May & Jun & Jul & Aug & Sep & Oct & Nov & Dec & $\mathrm{CV}, \%$ \\
\hline Fat, $\mathrm{g} / \mathrm{kg}$ & $37.2^{\mathrm{bc}}$ & $37.4^{\mathrm{bc}}$ & $37.4^{\mathrm{bc}}$ & $41.5^{\mathrm{a}}$ & $38.5^{\mathrm{b}}$ & $36.9^{c}$ & $35.2^{\mathrm{d}}$ & $35.0^{\mathrm{e}}$ & $33.8^{\mathrm{e}}$ & $34.8^{\mathrm{e}}$ & $34.1^{\mathrm{e}}$ & $36.9^{c}$ & 14.88 \\
\hline $\mathrm{PRO}, \mathrm{g} / \mathrm{kg}$ & $32.4^{\mathrm{efg}}$ & $32.6^{\mathrm{fg}}$ & $32.5^{\mathrm{efg}}$ & $34.0^{\mathrm{bc}}$ & $35.5^{\mathrm{a}}$ & $33.5^{\mathrm{cd}}$ & $31.8^{\mathrm{g}}$ & $32.2^{\mathrm{efg}}$ & $31.3^{\mathrm{h}}$ & $32.8^{\mathrm{de}}$ & $32.6^{\mathrm{ef}}$ & $34.3^{\mathrm{b}}$ & 7.87 \\
\hline $\mathrm{NFS}, \mathrm{g} / \mathrm{kg}$ & $85.8^{\mathrm{bc}}$ & $85.4^{\mathrm{c}}$ & $86.2^{\mathrm{bc}}$ & $87.5^{\mathrm{a}}$ & $87.4^{\mathrm{a}}$ & $87.6^{\mathrm{a}}$ & $86.3^{\mathrm{b}}$ & $86.7^{\mathrm{ab}}$ & $86.5^{\mathrm{b}}$ & $87.2^{\mathrm{a}}$ & $86.7^{\mathrm{ab}}$ & $84.5^{\mathrm{d}}$ & 3.72 \\
\hline $\log \mathrm{TBC}$ & $2.90^{\mathrm{ab}}$ & $2.80^{\mathrm{abc}}$ & $2.74^{\mathrm{c}}$ & $2.78^{\mathrm{bc}}$ & $2.79^{\mathrm{bc}}$ & $2.82^{\mathrm{abc}}$ & $2.54^{\mathrm{d}}$ & $2.79^{\mathrm{bc}}$ & $2.85^{\mathrm{abc}}$ & $2.75^{\mathrm{c}}$ & $2.92^{\mathrm{a}}$ & $2.84^{\mathrm{abc}}$ & 18.20 \\
\hline SCS & $5.05^{\mathrm{abc}}$ & $4.97^{\mathrm{abcd}}$ & $3.94^{\mathrm{e}}$ & $5.26^{\mathrm{a}}$ & $5.07^{\mathrm{ab}}$ & $4.89^{\mathrm{bcd}}$ & $4.81^{\mathrm{bcd}}$ & $4.89^{\mathrm{bcd}}$ & $4.78^{\mathrm{bcd}}$ & $4.76^{\mathrm{cd}}$ & $4.81^{\mathrm{bcd}}$ & $4.72^{\mathrm{d}}$ & 27.46 \\
\hline
\end{tabular}

${ }^{1} \mathrm{PRO}=$ protein $;{ }^{2} \mathrm{NFS}=$ nonfat solids; ${ }^{3} \log \mathrm{TBC}=$ base- 10 logarithm of the total bacterial count $;{ }^{4} \mathrm{SCS}=$ somatic cell score; ${ }^{6} \mathrm{CV}=$ coefficient of variation; (a,b,c,d,e,f,g,h) Means followed by different letter in the same row differ $(\mathrm{P}<0.10)$ by Student's $t$ test.

between samples, showed lower values in winter and higher in the spring $(\mathrm{P}<0.10)$. Probably, the lower temperatures and lower humidity in the milking environment are favorable to lowest result of TBC during the winter period (Table 2); these conditions are unfavorable for the bacterial proliferation in stored milk and milk contamination in the milking process, respectively. The higher values observed in the spring and summer must be a consequence of the onset of the rainy season and increase of temperatures. Bueno et al. (2008) observed a similar result with higher values of TBC during the rainy and warmer season. However, the high values of TBC (over 750,000 bacteria/mL or $\log$ TBC equal to 2.87) throughout the year, allow to infer that other non-climate factors are probably related to milking management, which are crucial to microbiological quality of milk in any production system (Nero et al., 2009).

The evaluation between year seasons showed significant differences $(\mathrm{P}<0.10)$; the autumn was the period with highest SCC; however, considering the months, only May had inferior average (Table 2). This difference in March, as well as in April, analyzing fat, presented differing value in comparison with all others and might have determined statistical differences in the analysis. The January and February months had similar values that are observed in the subsequent months of the autumn, except for May, which might indicate that without the presence of this outlier, there would probably be no differences between the autumn and other seasons. The variation in SCC observed (Table 2) did not follow the behavior described by Lacerda et al. (2010), who observed higher values in the spring and summer, which, according to the authors, promotes greater susceptibility of the teats of cows to environmental effects by higher relative humidity, higher temperatures and flooding.

There was significant effect $(\mathrm{P}<0.10)$ of transportation type on TBC (Table 3 ). The highest values for farmers using cartload and truck $(\mathrm{P}<0.10)$ allow us to infer that such logistic systems are less efficient compared with tanks. Farmers who use the car to take their milk to the platform had an intermediate TBC average, not unlike the other groups $(\mathrm{P}>0.10)$. For better evaluation of the systems, there should be monitoring of the evolution of TBC at all times of the logistics process, from milking to the loading on the communitarian tank platform. However, it can be observed that the milk the direct transport has lower TBC $(\mathrm{P}<0.10)$, probably because the milk goes through fewer steps under the influence of the environment and is rapidly cooled in expansion tanks at the property (Table 3 ).

There was no effect $(\mathrm{P}>0.10)$ of transport and refrigeration on the somatic cell score (Table 3 ), as expected because somatic cell is influenced by the mammary gland inflammation, else it does not change after the milk has been collected. 
Table 3 - Averages of total bacterial count and somatic cell count, according to different methods of transport and cooling of milk on the properties of the Pires Rural Producers Association (APRPires) in Juiz de Fora, Minas Gerais, Brazil

\begin{tabular}{|c|c|c|c|c|}
\hline & \multicolumn{4}{|c|}{ Transport } \\
\hline & Cart load & Truck & Car & Direct \\
\hline $\log \mathrm{TBC}^{1}$ & $2.83^{\mathrm{b}}$ & $2.82^{\mathrm{b}}$ & $2.57^{\mathrm{ab}}$ & $2.36^{\mathrm{a}}$ \\
\hline $\mathrm{CV}^{2}, \%$ & 17.85 & 16.55 & 23.75 & 27.28 \\
\hline $\mathrm{SCS}^{3}$ & $5.12^{\mathrm{ns}}$ & $4.77^{\mathrm{ns}}$ & $4.94^{\mathrm{ns}}$ & $5.15^{\mathrm{ns}}$ \\
\hline \multirow[t]{3}{*}{$\mathrm{CV}, \%$} & 24.58 & 29.15 & 24.03 & 13.73 \\
\hline & \multicolumn{4}{|c|}{ Cooling in the property } \\
\hline & Absent & Refrigerator & Immersion & Tank \\
\hline $\log \mathrm{TBC}$ & $2.86^{\mathrm{b}}$ & $2.77^{\mathrm{b}}$ & $2.76^{\mathrm{b}}$ & $2.36^{\mathrm{a}}$ \\
\hline $\mathrm{CV}, \%$ & 16.51 & 19.02 & 16.94 & 27.28 \\
\hline SCS & $4.58^{\mathrm{ns}}$ & $5.04^{\mathrm{ns}}$ & $5.11^{\mathrm{ns}}$ & $5.15^{\mathrm{ns}}$ \\
\hline $\mathrm{CV}, \%$ & 33.26 & 23.23 & 22.10 & 13.73 \\
\hline
\end{tabular}

${ }^{1} \log \mathrm{TBC}=$ base- 10 logarithm of the total bacterial count; ${ }^{2} \mathrm{CV}=$ Coefficient of variation; ${ }^{3} \mathrm{SCS}=$ somatic cell score; $\left({ }^{\mathrm{a}, \mathrm{b}}\right)$ Means followed by different letter in the same row differ $(\mathrm{P}<0,10)$ by Student's $t$ test; $\left({ }^{\mathrm{ns}}\right)$ Not statistically significant $(\mathrm{P}>0.10)$.

Among the types of cooling, the lower TBC values for private tank stand out $(\mathrm{P}<0.10)$, proving the effectiveness of the individual tanks in relation to the other groups, which use the community tank. According to Melo \& Reis (2007), the formation of associations of farmers in milk cooling tanks community can facilitate the improvement of quality; however, the statement of the authors were not confirmed in this study. Probably when the quality of the milk produced in associations is compared with the milk transported in churns to the industry; it is possible that the milk group has better quality. However, in this study a comparison was made with personal tanks, which are expected to be more efficient, because of the absence of transport steps.

The refrigeration method by immersion tanks is recognized by the Normative Instruction no. 51 (Brasil, 2002); however, this method similar $(P>0.10)$ to the use of refrigerators in relation to $\mathrm{TBC}$ and obtained higher values $(\mathrm{P}<0.10)$ when compared with individual tanks (Table 3). A reason for the inefficiency observed in the refrigeration with immersion tanks would be the misuse of the method by producers, with temperatures out of standards required by legislation and inefficient equipments. It is worth noting that in addition to the milking management, proper refrigeration is essential for maintaining the quality of the milk (Nero et al., 2009).

All farmers who do not refrigerate the milk in the property and perform a single milking use truck as transportation system. They obtained average TBC equal to those that use a refrigerator or immersion tank, and greater TBC when compared with those with private tank (Table 3). Possibly, the group should have good microbiological quality, since the time of milking to the arrival at the community tank, probably was low received little environmental influence. However, the group presented a high bacterial load, an unexpected result, since the time for bacterial growth is short. This result is an indication that the milking hygiene is not adequate in the period studied, and Vallin et al. (2009) classified this management factor as the main determining the milk quality in any production system.

Santana et al. (2001), assessing spots of contamination in milk production systems, found that, in addition to milking management, a major source of bacterial contamination are the churns, which were used in all refrigeration procedures except the private tank. It can be a major contributing factor to the higher $\mathrm{TBC}$ in the other refrigeration methods.

The group of farmers that performs a single milking had lower values $(\mathrm{P}<0.10)$ for SCS $($ Table 4$)$. One explanation for this result would be the possible fact that they had less specialized cows and low-production cows, which may have less scaling of alveolar cells of the udder in relation to higher-production cows, which, in two milking sessions, are more likely to scaling of the epithelium of the udder. Another factor is the greater somatic cell count in milk from the second milking performed in the animal (Vasconcelos et al., 1997). 
Table 4 - Averages of total bacterial count and somatic cell count according to the number of milkings in the Pires Rural Producers Association (APRPires) in Juiz de Fora, Minas Gerais

\begin{tabular}{lcc}
\hline & \multicolumn{2}{c}{ Number of milkings } \\
\cline { 2 - 3 } & One & Two \\
\hline $\operatorname{logTBC}{ }^{1}$ & $2.86^{\mathrm{ns}}$ & $2.72^{\mathrm{ns}}$ \\
$\mathrm{CV}^{2}, \%$ & 16.51 & 19.35 \\
$\mathrm{SCS}^{3}$ & $4.58^{\mathrm{a}}$ & $5.09^{\mathrm{b}}$ \\
$\mathrm{CV}, \%$ & 33.26 & 21.72 \\
\hline
\end{tabular}

${ }^{1} \log \mathrm{TBC}=$ base- 10 logarithm of the total bacterial count $;{ }^{2} \mathrm{CV}=$ Coefficient of variation; ${ }^{3}$ SCS $=$ somatic cell score; $(\mathrm{a}, \mathrm{b})$ Means followed by different letter in the same row differ $(\mathrm{P}<0,10)$ by Student's $t$ test; $\left({ }^{\mathrm{ns}}\right)$ Not statistically significant $(\mathrm{P}>0.10)$.

\section{CONCLUSIONS}

Year seasons affects the composition and quality of milk produced by the small farmers group. The refrigeration system and the type of transport influence the bacterial count of the milk. The number of milking sessions affects the milk somatic cell count.

\section{REFERENCES}

BRASIL. Instrução Normativa ${ }^{\circ} 51$, de 20 de setembro de 2002. Aprova os regulamentos técnicos de produção, identidade e qualidade do leite tipo... Diário Oficial da União, Brasília, p.13, 18 de setembro de 2002. Seção 1.

\section{BRITO, M.A.V.P.; DINIZ, H.D. Tanques de expansão comunitários para a refrigeração de leite. Juiz de Fora, MG: EMBRAPA - Empresa Brasileira de Pesquisa Agropecuária, 2004, (Comunicado Técnico, 41). Available in: <www.infoteca.cnptia.embrapa.br/ bitstream/doc/594947/1/COT41Tanquesdeexpansao. pdf>. Accessed on: April, 04, 2011.}

BUENO V.F.F.; MESQUITA, A.J.; OLIVEIRA, A.N. et al. Contagem bacteriana total do leite: relação com a composição centesimal e período do ano no Estado de Goiás. Revista Brasileira de Ciência Veterinária, Niterói, v.15, n.1, p.4044, January/April 2008.

DABDOUB, S.A.M.; SHOOK, G.E. Phenotypic relations among milk yield, somatic cell count, and clinical mastits. Journal of Dairy Science, Champaign, v.67 (Supplement 1), p.163-164, January, 1984.
GALAN, V.B. Avaliação da atividade de produção de leite e as novas tendências do mercado nacional. In: PEIXOTO, A.M., MOURA, J.C., FARIA, V.P. (Ed.). Planejamento da Exploração Leiteira. 1.ed. Piracicaba: FEALQ, 1998. p.257-268.

GONZÁLEZ, F.H.D. Composição bioquímica do leite e hormônios da lactação. In: GONZÁLEZ, F.H.D.; DURR, J.W.; FONTANELI, R.S. (Ed.). Uso do leite para monitorar a nutrição e o metabolismo de vacas leiteiras. 1.ed. Porto Alegre: Gráfica da Universidade Federal do Rio Grande do Sul, 2001. p.5-21.

JENKINS, T.C.; MCGUIRE, M.A. Major Advances in Nutrition: Impact on Milk Composition.

Journal of Dairy Science, Champaign, v.89, n. 4, p.1302-1310, April, 2006.

KALSCHEUR, K.F.; BALDWIN, R.L.; GLENN, B.P. et al. Milk production of dairy cows fed differing concentrations of rumen-degraded protein. Journal of Dairy Science, Champaign, v. 89, n.1, p.249-259, January, 2006.

LACERDA, L.M.; MOTA, R.A.; SENA, M.J. Contagem de células somáticas, composição e contagem bacteriana total do leite de propriedades leiteiras nos mnicípios de Miranda do Norte, Itapecurú-mirim e Santa Rita, Maranhão. Arquivos do Instituto Biológico, São Paulo, v.77, n.2, p.209-215, April/June 2010.

LOPES, P.F.; REIS, R.P.; YAMAGUCHI, L.C.T. Custos e escala de produção na pecuária leiteira: estudo nos principais estados produtores do Brasil. Revista de Economia e

Sociologia Rural, Brasília, v.45, n.3, p.567590, July/September, 2007.

MELO, A.D.S.; REIS, R.P. Tanques de expansão e resfriamento de leite como alternativa de desenvolvimento regional para produtores familiares. Organizações Rurais \& Agroindustriais, Lavras, v.9, n.1, p.111-122, 2007.

NERO, L.A.; VIÇOSA, G.N.; PEREIRA, F.E.V. Qualidade microbiológica do leite determinada por características de produção. Ciência e Tecnologia de Alimentos, Campinas, v.29, n.2, p.386-390, April/June, 2009. 
ROMA JUNIOR, I.C.; MONTOYA, J.F.G.; MARTINS, T.T. et al. Sazonalidade do teor de proteína e outros componentes do leite e sua relação com programa de pagamento por qualidade. Arquivo Brasileiro de Medicina Veterinária e Zootecnia, Belo Horizonte, v.61, n.6, p.1411-1418, december, 2009.

SANTANA, E.H.W.; BELOTI, V.; BARROS, M.A.F. et al. Contaminação do leite em diferentes pontos do processo de produção: 1. Microrganismos aeróbios mesófilos e psicotróficos. Semina: Ciências Agrárias, Londrina, v.22, n.2, p.145154, July/December, 2001.

TEIXEIRA, N.M.; FREITAS, A.F.; BARRA, R.B. Influência de fatores de meio ambiente na variação mensal da composição e contagem de células somáticas do leite em rebanhos no Estado de Minas Gerais. Arquivo Brasileiro de Medicina Veterinária e Zootecnia, Belo Horizonte, v.55, n.4, p.491-499, August, 2003.
VALLIN, V.M.; BELOTI, V.; BATTAGLINI, A.P.P. et al. Melhoria da qualidade do leite a partir da implantação de boas práticas de higiene na ordenha em 19 municípios da região central do Paraná. Semina: Ciências Agrárias, Londrina, v.30, n.1, p.181-188, January/March, 2009.

VASCONCELOS, C.G.C.; NADER FILHO, A.; AMARAL, L.A. et al. Influência da estação do ano, do estádio de lactação e da hora da ordenha sobre o número de células somáticas do leite bovino. Arquivo Brasileiro de Medicina Veterinária e Zootecnia, Belo Horizonte, v.49, n. 4, p.483-491, August, 1997.

ZOCCAL, R.; SOUZA, A.D.; GOMES, A.T. Produção de leite na agricultura familiar. In: MARTINS, C.E. ET al. (Ed.). Tecnologias alternativas para a produção de leite e derivados em bases sustentáveis. 1.ed. Juiz de Fora: Embrapa Gado de Leite, v.1, p.19-34, 2004.

Recebido para publicação em 29/04/2015 e aprovado em 11/02/2016. 